THURSDAY, AUGUST 27, 1896.

\section{PROFESSOR OSTWALD ON ENGLISH AND GERMAN SCIENCE.}

PROF. RAMSAY has, done good service by communicating to the Times a letter he has received from Prof. Ostwald of the highest importance at the present time, when, fortunately for us, German supremacy along many lines of applied science and the causes of it, are being at last recognised.

No one has a better right to speak on this subject than Prof. Ostwald, and the fact that we may take his communication as one made in the interests of British science makes it all the more valuable.

What he says will be no news to the readers of NATURE, because for years past we have been pointing out the rocks ahead and the steps necessary to avoid them ; but our voice has been as that of one crying in the wilderness. Fortunately for us this is so no longer. The Times devotes a leader to Dr. Ostwald's letter, which we give in another column, but it does not appear that even the Times is in real touch with the actual position.

"The Germans have found that nothing pays so well as knowledge, and that new knowledge always pays in the long run. They act on this principle by maintaining a steady demand for men competent to extend the domain of theoretical knowledge, paying them well for doing it, and taking their chance of one valuable practical discovery turning up among a score that for the present lead to nothing. How good that chance is may be judged from the enormous success attending German chemical industries of all kinds. Germany controls the fine chemical markets of the world, and that means that she takes tax and toll of almost every industry in every country. How easily we might have forestalled her can be fully understood only by those who know what a splendid start we had in capital, in machinery, in control of markets, and in root ideas. Some of her most lucrative industries have been developed out of English discoveries, due to the genius of individual Englishmen, but never properly grasped and worked out by English manufacturers. Her commercial domain will go on extending, and ours proportionately shrinking, unless Englishmen become practical enough to look beyond their noses, and wise enough to believe in knowledge."

This is excellent ; but then we are also told--

"For any healthy reform we want driving power, and the driving power must come from manufacturers enlightened enough to understand the secret of German success and English failure. It is industry that must endow research, not from any unpractical desire to add to the number of useless persons who know all that has been done, yet do not know how to do anything new, but from the very practical desire of manufacturers to extend their business and add to their profits."

And again :-

"There is a clamour now and again for State aid, and Dr. Ostwald's letter will, perhaps, stimulate it, because he refers to the action of the State in Germany. But the root of the matter in Germany lies in private enterprise, and it must do so here. Heaven helps those who help themselves, and the State cannot do better than observe the same limitation. When industry endows research it will be time to ask for assistance from the taxpayer.

NO. I 40O, VOL. 54]
Until then State endowment of research can mean little more than throwing money away upon abstract acquirements having no real relation to the facts of national prosperity."

Let us accept for a moment that "industry," "manufacturers," and "private enterprise" in Britain at once proceed to do all that the Times lays at their doors. What then? Prof. Ostwald answers this question by telling us what the Prussian Government and the various German States have done and are doing for research and scientific education, above and beyond all the efforts made by German "industry," "manufacturers," and "private enterprise."

In such a competition Britain, without the State aid so amply and wisely given in Germany, is certain to lose.

It has already been pointed out in these columns, and it is worth while to re-state it, that the connection between our national greatness, our national defences, and our commerce, is universally recognised, and that the State spends, and properly spends, tens of millions a year, the protection of our commerce being assigned as one of the ostensible reasons.

But another thing which as yet is not generally recognised is that so surely as our national greatness is based upon our industries, as surely in the future must our industries be based upon science.

It is clear, therefore, that if in other countries the advancement of science is the duty not only of individuals, but of States, mere individual effort in any one country must be crushed out in the international competition which is growing keener and keener every day.

Taking things as we find them, we spend tens of millions a year to protect our commerce which is a measure of our industries; while the basis of these, science, is to remain unprotected, unorganised, and unaided, except by local efforts and the action of individuals.

Surely such a contention cannot be seriously maintained-such inconsistent action can have no logical basis. The real remedy lies in consistently organising both our peace and our war forces, as Huxley pointed out many years ago. We have now a War or Industries-protecting Council : by the side of it we want a Peace or Industries-producing Council ; in other words, a strong Minister of Science, who shall have as complete a staff of men of science to advise him as the President of the War Council finds himself provided with in the heads of the Army and Navy Departments.

Only in this way can Germany's flank be turned. If it were only a question of ironclads how readily everybody would agree.

Another part of Prof. Ostwald's letter, for which thanks are due, is that in which he points out that in Germany research is as important an engine in Education as it is in a Chemical Works; so that again the call upon "private enterprise" is not sufficient.

Here, of course, the whole question of our University organisation is raised. We cannot pursue it now, but we may quote a pregnant passage from Prof. Fitzgerald's letter, also printed elsewhere-

"The most serious cause of complaint of modern society against the old universities is that they have so controlled 
the education of the wealthy classes of the community, that the landed and professional classes have been educated apart from the commercial and industrial classes, to the very great injury of both."

This is the reason that the true condition of things has not been appreciated long ago. It is not understood, and therefore it is not believed. Our political leaders, the permanent chiefs of the various public departments, have not the slightest idea what all this fuss is about, because their education has been entirely apart from those regions of thought and work in which in the future the peaceful battles of the world will be fought and won; if not by us, then by others, for fighting there must be.

No better argument could be found for the establishment of a ministry and council of science than was afforded by two speeches delivered some little time ago by the Duke of Devonshire on matters connected with scientific education, and of which condensed reports were given in NATURE at the time. The Duke candidly confessed at Birmingham that he was not placed at the head of the educational and scientific affairs of the country on account of any special knowledge of the subjects, for "his knowledge of science and art could be compressed into two nutshells." It is not our desire to utter one word against the Duke of Devonshire for his candour; he has shown that he is interested in technical education, and has on more than one occasion assisted the work of science. But what we do criticise is the political system which does not consider it necessary that the educational and scientific welfare of the country should be the business of those who are able to appreciate the work done, to see the necessity of reforms, and to know the directions in which developments should take place. In almost every other country the State or Government has official men of science among its servants, and also constantly ask the advice and assistance of their academies and learned societies, when questions of technical and scientific interest are being discussed; but here no such use is made, either of the societies as a whole or of the men who constitute them.

\section{CARL VOGT.}

La Vie d'un Homme: Carl Vogt. By William Vogt. 4to vol. of 264 pages, with two portraits by Otto Vautier. (Schleicher Brothers, ex-Reinwald. Paris, I 896.)

A PHILOSOPHER he was--there is no doubt about A that ; but none of the quiet sort who "leave controversy to the little world below them": he was one of the fighting portion, and while none have known him to step out of his path to avoid a skirmish, he has often gone far from his track for the mere pleasure of picking up some battle. To him life was movement, and a true account of his years should include more than the history of his scientific work. The latter has been reviewed in NATURE for May 30, 1895, and a very full account thereof has been also given by his pupil and friend, Emile Yung, in Revue Scientifique, dated June 22, I 895 . M. William Vogt, his son, now proceeds to tell us the essentials of NO. I 40O, VOL. 54] his life; and although the large book before us deals but slightly with the scientific features of the lamented naturalist, still scientific readers will find much in it to interest them, in the way of anecdotes concerning Vogt's relations with men of his time, and letters of the latter.

Carl Vogt was born on July 5, I8I7, at Giessen, in Germany, the eldest of nine children. Celtic blood was predominant in his veins, not Germanic, and much in his character and wit was distinctively Celtic. The son of a distinguished physician and professor, Carl had an uneventful youth. To put it short, he was lazy, and Gall could certainly not locate the "bump of respect" or of subinissiveness on that head. His father was assured that the masters allowed him to pass from class to class, each year, only to get rid of this turbulent and undisciplined pupil ; and it is well known that the aforesaid "bump" never grew. After the school-days, Carl was sent to the medical faculty, where he did more fighting and duelling than reading or study, and entered Liebig's laboratory. He was engaged in an investigation of the amniotic liquid (published in Müller's Archiv, r 837), when an event occurred which stands at the basis of all Vogt's political troubles. A law student, implicated in the Marburg plot, and a republican, begged of Vogt to help and conceal him, as the police were in search of him. Vogt-a nephew of the three republican brothers Folleniuscomplied immediately, and hid his fellow-student in his own room, although the next day it was officially announced that five years' imprisonment in a fortress was the penalty for such offence. A week elapsed, quietly, when one day, Liebig took Vogt aside. Liebig knew the facts, and had heard that the police also were informed; it was high time for Vogt to run. At once Vogt went home, and the same evening the refugee and himself left, in opposite directions, early enough to avoid being captured. Carl Vogt fled to an uncle of his, near Darm. stadt, and spent a few weeks there, disguised by his uncle-an inspector of forests-as a forest official, and in this character taking part in the chases of the very GrossHerzog himself, whose police were after Vogt. Some weeks later, he managed to cross the Rhine, and, with the help of friends, to put his feet on the French soil ; he was then out of trouble. His father desired him to pursue his medical studies, and in 1839 he graduated in Bern maxima cum laude. But little he cared about medical art. Valentin, the physiologist and anatomist, had been interested in the young student, and wished to bring him over to zoology and physiology. Vogt took very kindly to the hints, and to Valentin's lessons, and undertook most willingly to investigate the nervous system of some South American reptiles collected by Humboldt. Hence two papers ("Neurologie von Python tigris" and "Neurologie der Reptilien," I839-40) which are the first anatomical work of Carl Vogt, the last being more than fifty years younger. At this period, circumstances-too long to relate-- put Vogt, and Edouard Desor his friend, in contact with Louis Agassiz, and they decided of Vogt's scientific future: he was bound to become a naturalist. Vogt set to work in most determined manner at Agassiz's "Poissons d'Eau douce" and at the "Embryologie des Salmonés," publishing in the meantime his 